\title{
Experimental Analysis on Fractional Replacement of Fine Aggregate with Granite Dust and Coarse Aggregate with Mosaic Tile
}

\author{
Rakhi Wankhede ${ }^{1}$, Prof. G.D.Awchat ${ }^{2}$ \\ ${ }^{I}$ Student ${ }^{2}$ Assistant Professor \\ Gurunanak Institute of Technology, Nagpur,, India, 441501
}

Received on: 08 June, 2021

Revised on: 10 July, 2021

Published on: 12 July, 2021

\begin{abstract}
Studies show that about 20-30\% of material prepared in the tile manufacturing plants are transforming into waste. This waste material should have to be reused in order to deal with the limited resource of natural aggregate and to reduce the construction wastes. Crushed waste mosaic tiles and Granite powder are used as a replacement to the coarse aggregates and fine aggregate. The waste crushed tiles were partially replaced in place of coarse aggregates by $10 \%, 20 \%, 30 \%, 40 \%$ and 50\%. Granite powder was replaced in place of fine aggregate by $10 \%$ along with the ceramic coarse tile. M25 grade of concrete was designed and tested. The mix design for different types of mixes were prepared by replacing the coarse aggregates and fine aggregate at different percentages of crushed tiles and granite powder. Experimental investigations like workability, Compressive strength test, Split tensile strength test for different concrete mixes with different percentages of waste crushed tiles and granite powder after 7, 14 and 28 days curing period has done. It has been observed that the workability increases with increase in the percentage of replacement of granite powder and crushed tiles increases. The strength of concrete also increases with the ceramic coarse tile aggregate up to $30 \%$ percentage.
\end{abstract}

Keywords-Crushed mosaic tiles, Compressive strength, Granite powder, Split Tensile strength

\section{I- INTRODUCTION}

Due to the modern civilization, the solid waste from the demolition of constructions is increasing day by day. Also there is a huge usage of tiles in the present constructions and it is increasing in day by day. Ceramic products are part of the essential construction materials used in most buildings. Some common manufactured ceramics include wall tiles, floor tiles, sanitary ware, household ceramics and technical ceramics and faucets. They are mostly produced using natural materials that contain high content of clay minerals. However, despite the ornamental benefits of ceramics, its wastes among others cause a lot of disturbance to the environment. And also on the other side waste tile is also producing from demolished wastes from construction. Indian tiles production is 750 million per year in the industry, about 15\%-30\% waste material generated from the total production. This waste is not recycled in any form at present, however the ceramic mosaic waste is durable, hard and highly resistant to biological, chemical and physical degradation forces so, we selected these waste tiles as a replacement material to the basic natural aggregate to reuse them and to decrease the solid waste produced from demolitions of construction. Waste tiles and granite powder were collected from the surroundings.

\section{II- $\quad$ EXPERIMENT DETAILS}

Different types of mixes were prepared by changing the percentage of replacement of coarse and fine aggregates with crushed tiles and granite powder. 


\section{International Journal of Innovations in Engineering and Science, www.ijies.net}

Total 10 types of mixes are prepared along with conventional mixes. The coarse aggregates are replaced by $10 \%, 20 \%, 30 \%, 40 \%$ and $50 \%$ of crushed tiles and the fine aggregate is replaced by $10 \%$ of granite powder along with the coarse aggregate.

\section{III- TEST RESULTS}

Slump Cone Test. The test was conducted for fresh concrete prepared before the moulding process. A total of 14 concrete mixes are prepared at different times. Workability Results obtained from slump cone test for M25 grade of concrete is shown in table.

\begin{tabular}{|c|c|c|c|}
\hline \multirow[t]{2}{*}{ S.Yia } & \multirow{2}{*}{$\frac{\text { Mix }}{\text { Desibzatiou }}$} & \multirow{2}{*}{$\begin{array}{c}\text { Agurgale } \\
\text { Replacements of } \\
\text { (CCA+GP) }\end{array}$} & \multirow{2}{*}{$\begin{array}{c}\begin{array}{c}\text { Wotkabein } \\
\text { (mm) }\end{array} \\
\text { Jns }\end{array}$} \\
\hline & & & \\
\hline I & $\mathbf{M 0}$ & $0+0$ & $6 \theta$ \\
\hline 2 & M1 & $20+0$ & 72 \\
\hline 3 & 32 & $20-0$ & 74 \\
\hline 4 & 313 & $30+0$ & 7 \\
\hline 5 & $\mathrm{M} 4$ & $40+0$ & $B 1$ \\
\hline 6 & MS & $50 \div 0$ & 83 \\
\hline 7 & M16 & $10+10$ & 76 \\
\hline 8 & $\mathrm{M} 7 \mathrm{7}$ & $20+10$ & 82 \\
\hline 9 & M8 & $30+10$ & 94 \\
\hline 18 & 39 & $40+10$ & 92 \\
\hline
\end{tabular}

Compressive Strength:

A total of 30 cubes of size $150 \times 150 \times 150 \mathrm{~mm}$ were casted and tested for 7 days, 14 days and 28 days testing each of 10 specimens after conducting the workability tests. The results are tabulated below:

\begin{tabular}{|c|c|c|c|c|c|}
\hline \multirow[t]{2}{*}{$3 N_{0}$} & \multirow{2}{*}{$\begin{array}{c}\text { Mix } \\
\text { Designation }\end{array}$} & \multirow{2}{*}{$\begin{array}{c}\text { Aggregate } \\
\text { Replacements \% } \\
\text { (CCA+GP) }\end{array}$} & \multicolumn{3}{|c|}{$\begin{array}{c}\text { Compressive strength of M25 } \\
\text { grade in N/mm? }\end{array}$} \\
\hline & & & 7 days & 14 days & 28 days \\
\hline & Mo & $0 \div 0$ & 20.36 & 28.25 & 32.85 \\
\hline 2 & Ml & $10 \div 0$ & 23.85 & 31.08 & 36.14 \\
\hline 3 & M2 & $20 \div 0$ & 26.01 & 32.47 & 39.11 \\
\hline 4 & M3 & $30 \div 0$ & 27.77 & 37.15 & 42.71 \\
\hline 5 & M4 & $40 \div 0$ & 23.72 & 31.45 & 36.79 \\
\hline 6 & M5 & $50+0$ & 22.00 & 28.59 & 33.84 \\
\hline 7 & M6 & $10+10$ & 20.84 & 28.35 & 34.16 \\
\hline 8 & M7 & $20+10$ & 24,35 & 33.24 & 39.11 \\
\hline 9 & M8 & $30+10$ & 27.82 & 38.02 & 41.72 \\
\hline 10 & M9 & $40+10$ & 21.11 & 27.81 & 33.50 \\
\hline
\end{tabular}

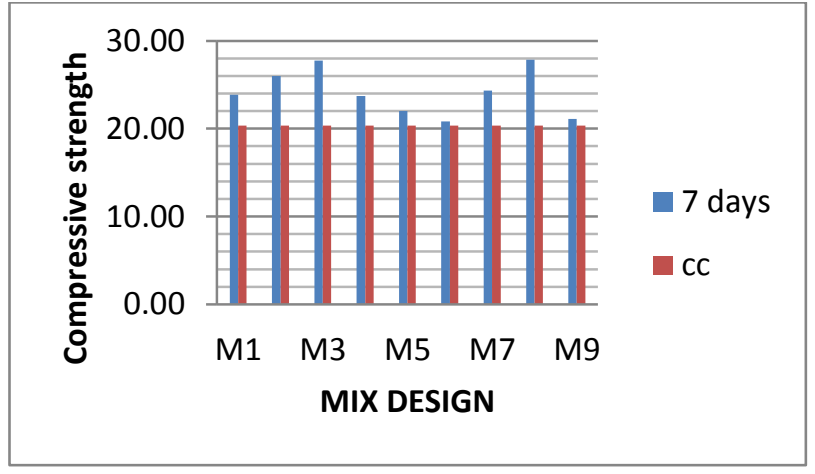

Comparison of Compressive strength of M25 at 7 days

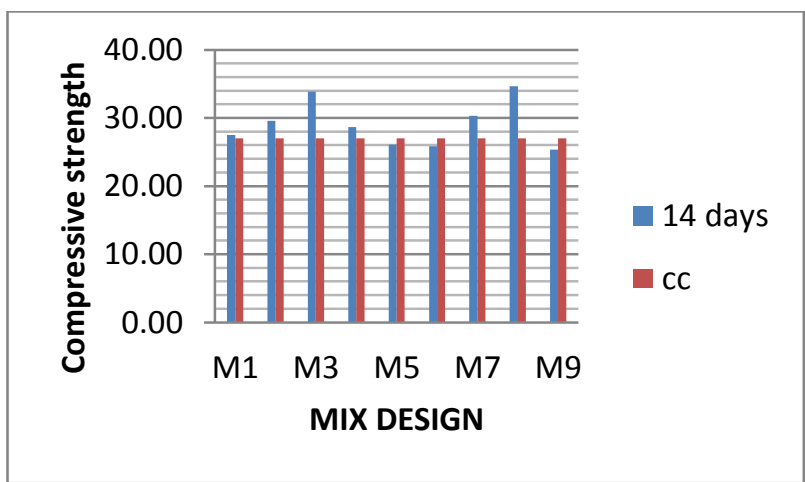

Compressive strength of M25 concrete at 14 days

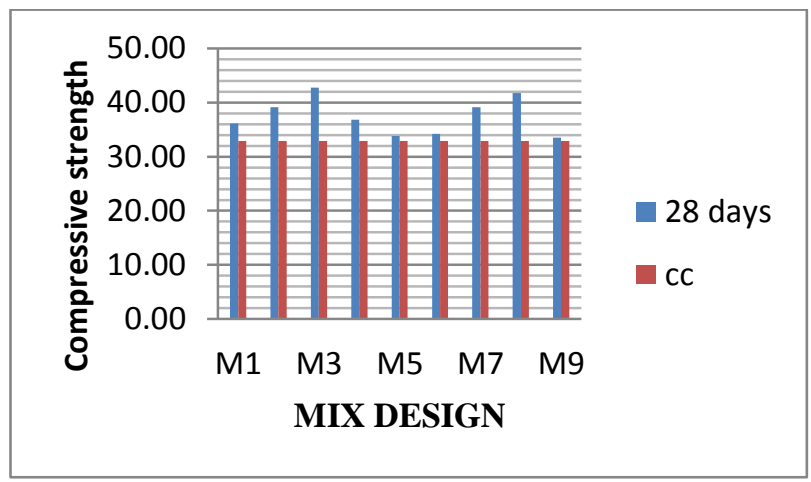

Compressive strength of M25 concrete at 28 days

\section{Split Tensile Strength:}

The split tensile strength obtained by testing the cylindrical specimen for M25 grade of concrete to all the mixes designed for various replacements are given below. The replacement of aggregates by various proportions has positive effect on the strength of the concrete. 


\section{International Journal of Innovations in Engineering and Science, www.ijies.net}

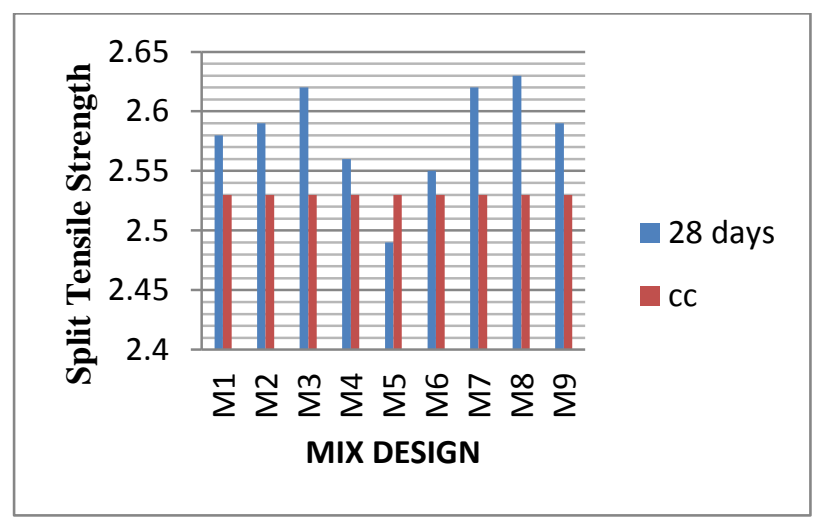

Split tensile strength of M25 at 28 days

\section{IV - CONCLUSION}

The following conclusions are made based on the experimental investigations on workability, compressive strength, split tensile strength considering the environmental aspects also:

The workability of concrete increases with the increase in tile aggregate replacement. The workability is further increased with the addition of granite powder which acts as admixture due to its chemical properties.

The properties of concrete increased linearly with the increase in ceramic aggregate up to $30 \%$ replacement later it is decreased linearly.

M3 \& M8 mix of concrete produced a better concrete in terms of compressive strength, split tensile strength than the other mixes. But the mixes up to $50 \%$ of ceramic coarse aggregate can be used.

The addition of tiles waste can cut the cost of coarse aggregate so as the cost of construction.
The split tensile strength of ceramic tile aggregate is very much in a straighter path compared to the conventional grades of concrete.

\section{REFERENCES}

[1] G.Sai Chand, P.Ravi Kumar, IJOER:eISSN: 2321-7758| Vol.5., Issue.3, 2017.

[2] Batriti Monhun R. Marwein, M. Sneha, I. Bharathidasan International Journal of Scientific \& Engineering Research, Volume 7, Issue 4, April-2016 ISSN 2229-5518.

[3] Iranian Journal of Science \& Technology, Transaction B, Engineering, Vol. 31, No. B5, pp 561-565 Printed in The Islamic Republic of Iran, 2007

[4] Department of Engineering and Agricultural Sciences, University of Leon, Avenida Portugal 41, Leon 24071, Spain.

[5] International Journal of Innovative Research in Science,Engineering and TechnologyISSN(Online): 23198753 ISSN (Print): 2347-6710.

[6] N.Naveen Prasad, P.Hanitha, N.C.Anil IOSR Journal of Mechanical and Civil Engineering (IOSR-JMCE) e-ISSN: 2278-1684,p-ISSN: 2320-334X, Volume 13, Issue 6 Ver. V (Nov. - Dec. 2016), PP 168-176.

[7] Journal of Multidisciplinary Engineering Science and Technology (JMEST) ISSN: 3159-0040 Vol. 2 Issue 11, November - 2015

[8] Paul O. Awoyera, Julius M. Ndambuki, Joseph O. Akinmusuru, David O. Omole-4048 2016 Housing and Building National Research Center. Production and hosting by Elsevier B.V. 15 November 2016) 